Syntax Fusion : Jurnal Nasional Indonesia

p-ISSN: -

e-ISSN : 2775-4440

Vol. 1, No. 7, Juli 2021

\title{
PANDANGAN AGAMA TERHADAP BUDAYA TRADISIONAL PEREMPUAN INDONESIA
}

\author{
Indra Ramdhani \\ UIN Sunan Gunung Djati Bandung \\ iramdhani737@gmail.com
}

\begin{abstract}
Abstrak
Artikel ini mengkaji mengenai sudut pandang agama terhadap budaya tradisional perempuan Indonesia, dengan memfokuskan kajian pada busana kebaya perfektif agama Islam. Kebaya merupakan salah satu identitas dari perempuan yang ada di Indonesia dan merupakan suatu prodak dari budaya nusantara. Namun pada aspek lain perlu di perhatikan juga bahwa mayoritas dari perempuan Indonesia adalah seorang muslimah yang notabene dalam ajaran agama Islam sendiri telah diatur sedemikian rupa mengenai tata cara berpakaianya yakni dapat menutupi aurat, tidak memperlihatkan bentuk lekuk tubuh, serta tidak menampkan sisi sensualitas dari perempuan yang dalam hal ini dapat merangsang gairah syahwat lawan jenisnya. Hal tersebut bertujuan untuk memuliakan kehormatan serta martabat perempuan itu sendiri dan juga mencegah terjadinya hal-hal yang justru malah merugikan kaum perempuan. Sehingga apabila busana kebaya yang digunakan tersebut sesuai dengan aturan yang ada dalam agama Islam maka boleh-boleh saja dikenakan oleh seorang muslimah, akan tetapi jika hal tersebut malah bertentangan maka tidak diperbolehkan untuk dikenakan.
\end{abstract}

Kata Kunci: Budaya Tradisional, Agama, Perempuan

\section{Pendahuluan}

Sebagai suatu negara yang majemuk, Indonesia memiliki kekayaan identitas yang beragam pada konteks kehidupan bermasyarakatnya. Fakta tersebut dapat terlihat dari beberapa indikator antara lain: Pertama, beragamnya suku bangsa Indonesia yang kemudian terbingkai dalam satu kesatuan diantaranya suku jawa, sunda, minahasa, bugis, batak, juga suku-suku lainya. Kedua, memiliki keanekaragaman kepercayaan baik berupa agama (Islam, Katolik, Protestan, Hindu, Budha, dan Konghucu) ataupun kepercayaan lokal (sunda wiwitan, kejawen, kaharingan dan lain sebaginya). Ketiga, mempunyai keanekaragaman bahasa yang merepresentasikan daerahnya masing-masing (bahasa sunda, jawa, banjar, serta bahasa lainya). keempat, terdapat keanekaragaman budaya yang tercipta sebagai hasil dari keragaman suku bangsanya. (Antara \& Yogantari, 2018). 
Hal tersebut memberikan gambaran bahwa Indonesia merupakan negara dengan keangekaragaman terbesar di dunia yang kemudian mempunyai identitas tersendiri dan membentuk menjadi satu kesatuan, yang dalam konteks ini mempertegas negara Indonesia menjadi salah satu negara dengan keragaman corak budaya didalamnya sehingga melekat menjadi salah satu ciri khas dari negara berkebudayaan.

Aspek kebudayaan tersebut terbentuk dari kearifan lokal daerahnya masingmasing yang dalam hal ini memiliki kehasanya tersendiri. Kearifan lokal adalah suatu konsep yang mengacu pada aspek pengetahuan seseorang yang tinggal di daerah tertentu secara bersamaan, serta merupakan cerminan dari hasil persepsi, intuisi, dan pemahaman sebagai hasil dari adanya interaksi sosial. Sehingga membentuk menjadi suatu kebudayaan, norma, serta kepercayaan yang direalisasikan dalam bentuk mitos dan tradisi yang kemudian dianut dalam rentan waktu yang panjang (Inawati, 2014).

Sebagai suatu ciri khas dan identitas Indonesia, eksistensi dari kearifan lokal sudah semestinya dijaga dan dipelihara agar tidak tergerus oleh arus globalisasi yang saat ini justu semakin merebak dalam kehidupan masyarakat Indonesia. Aspek modernitas yang mengikuti trend barat atau juga budaya asing lainya jutru secara bersamaan dapat mengikis unsur kearifan budaya lokal nusantara. Sehingga penguatan dari jati diri identitas kultural sangat penting dilakukan agar prodak dari kearifan lokal tersebut bisa di wariskan secara turun temurun kepada generasi selanjutnya yang juga secara bersamaan memiliki peran penting dalam menjaga dan melestarikannya.

Peranan tersebut dapat dilakukan oleh seluruh masyarakat Indoensia, termasuk juga perempuan yang dalam konteks ini merupakan bagian dari warga negara Indonesia. Yang mana pada era modern seperti sekarang ini isu kesetaraan gender menjadi salah satu bagian terpenting dalam aspek kehidupan masyarakat Indonesia, sehingga perempuan juga memiliki hak dan kewajiban yang sama dalam konstuksi sosial masyarakatnya terkhusus dalam hal ini untuk menjaga serta melestarikan nilai-nilai budaya nusantara. Meskipun pada faktanya terkadang tradisi dan budaya tersebut mendiskriminasi posisi dari kaum perempuan itu sendiri, namun dalam hal ini tidak menjadi hambatan bagi perempuan untuk ikut serta berperan dalam konteks kehidupan bersosialnya (Nurul, 2018). Yang pada saat bersamaan dapat mengikis persepsi terhadap perempuan yang kerapkali di pandang sebelah mata dalam konteks kehidupan bermasyarakat.

Adanya pengklasifikasian antara superior dan inferior tersebut, memunculkan persepsi bahwa perempuan hanya dapat berperan dalam aspek domestiknya saja. Sehingga budaya patriarki tersebut membatasi peran perempuan dalam konteks sosialnya yang kemudian tidak sedikit para kaum perempuan takut untuk mengemukakan dan mengkespresikan hak-haknya sebagai bagian dari warga negara yang notabene memiliki hak serta kewenangan yang sama dalam mengutarakan gagasan dan pendapatnya (Mustofa et al., 2019).

Dari beragamnya konteks kebudayaan Indonesia, busana kebaya menjadi salah satu bagian dari prodak budaya nusantara tersebut. Kebaya yang awalnya hanya merupakan baju kedaerahan tertentu namun dengan perkembanganya terakui sebagai 
salah satu busana nusantara yang kemudian diklaim menjadi busana nasional serta menjadi cultural display bangsa Indonesia itu sendiri (Trismaya, 2019).

Dalam konteks sejarahnya memang kebaya telah lama dipilih oleh perempuan Indonesia sebagai salah satu pakaian khas mereka, hal tersebut bisa terlihat dari dilegitimasinya kebaya sebagai busana identitas nasional Indonesia sejak tahun 1940an. Selain menjadi salah satu prodak dari budaya nusantara, kebaya juga menjadi suatu cerminan dari pola perilaku perempuan Indoensia yang pada awalnya memberikan karakteristik pada aspek kesopanan, keanggunan yang melambangkan identitas dari perempuan yang ada di Indonesia. (Suciati et al., 2015) Maka dalam hal ini, kebaya dan Perempuan Indonesia memiliki keterkaitan yang sangat erat juga saling mempengaruhi antara satu dengan yang lainya.

Pada aspek lainya, busana kebaya dapat diaplikasikan oleh perempuan Indonesia sebagai perwujudan dari presensi kesetaraan gender dalam ranah sosial kemasyarakatan. Yang mana memberikan suatu makna bahwa perempuan juga mempunyai peranan yang penting dalam pelestarian budaya nusantara. Sehingga dapat memunculkan suatu pandangan terhadap eksistensi perempuan dalam ranah hirarki kesosialanya, karena dalam hal ini busana kebaya merupakan kulit sosial dalam suatu kebudayaan nusantara yang dapat memberikan persepsi pada penggunanya (Rositadewi, 2020).

Namun dalam hal ini perlu diperhatikan kembali bahwa pada faktanya negara Indonesia menjungjung tinggi nilai-nilai keagamaan dalam kelangsungan hidupnya. Maka dalam konteks ini, perempuan Indonesia dihadapkan pada dua sisi yaitu selain memiliki kewenangan dalam melestarikan budayanya pada sisi lain harus mencermati juga aspek keagamaan, yang mana kebaya tidak hanya memrepresentasikan suatu pakain tertentu akan tetapi juga membentuk persepsi pada pemakainya. Sehingga dalam membangun makna tubuhnya, perempuan harus lebih berhati-hati agar tidak merugikan atau justru malah merendahkan derajat perempuan tersebut yang notabene dijungjung tinggi harkat derajat serta martabatnya terkhusus oleh agama Islam.

Fakta menunjukan bahwa seiring dengan perembangan zaman, busana kebaya justru malah bertentangan dengan aspek ajaran agama Islam. Yang mana dengan bentuk serta polanya malah memperlihatkan "kesexyan" lekuk tubuh dari perempuan dan tak jarang menampakan aspek sensualitasnya. Hal tersebut justru menimbulkan stigma yang negatif dalam kacamata agama Islam yang notabene sangat memperhatikan aspek tersebut. Sehingga sebagai seorang muslimah perlu untuk memegang teguh aturan berpakaian yang ada dalam agama Islam yang pada hakikatnya menjungjung tinggi nilai kehormatan serta martabat seorang perempuan. Jangan sampai tunduk pada suatu tradisi budaya yang justru memberikan kemadaratan bagi perempuan itu sendiri, karena memang seiring dengan berkembangnya model busana kebaya yang justru mengandung doktrin paradigma sekuler salah satunya dengan penetapan pemakaian konde dalam sperangkat aturan berbusana kebaya dan hal tersebut malah memperlihatkan aurat dari perempuan yaitu rambut (Rahmawati, 2017). Meskipun dalam hal ini para ulama berbeda pendapat dalam menentukan hukum rambut perempuan menjadi salah satu bagian dari aurat yang 
harus di tutupi, namun lumrahnya dari ulama kebanyakan tidak memperbolehkan rambut perempuan ditampakan pada orang yang bukan muhrimnya (khalayak umum).

Maka dari permasalahan tersebut, penulis tertarik untuk mencoba mengkaji busana kebaya dalam sudut pandang agama Islam dengan seperangkat aturan hukumnya mengenai pakaian yang seharusnya dikenakan oleh seorang perempuan terkhusus dalam hal ini muslimah yang ada di Indonesia serta bagaimana seharusnya mereka menyikapi busana kebaya tersebut yang pada satu sisi merupakan suatu identitas perempuan Indonesia dan pada sisi lain cara berpakaian seorang muslimah juga telah diatur dalam ajaran agama Islam.

\section{Metode Penelitian}

Metode penelitian yang digunakan dalam penulisan ini yaitu dengan menggunakan metode studi kepustakaan (library research). Dimana menurut M. Nazir dalam (Amiroh et al., 2018), studi kepustakaan merupakan suatu teknik pengumpulan data dengan mengkaji berbagai macam sumber literatur, laporang-laporan, serta bukubuku yang berkaitan. Yang mana pada penelitian ini, penulis juga merujuk pada sumber litelatur agama Islam yaitu Al-Quran, hadits, serta sumber hukum lainya yang mendukung penulis dalam menganalisis serta menjawab permasalahan yang ada dalam penelitian ini.

\section{Hasil Dan Pembahasan}

\section{Kebaya Sebagai Bentuk Budaya dan Identitas Perempuan Indonesia.}

Istilah "budaya" dalam Kamus Besar Bahasa Indonesia (KBBI) memiliki beberapa penegertian diantaranya: Pertama, budaya adalah pikiran akal budi seseorang. Kedua, budaya merupakan suatu adat istiadat (kultur). Ketiga, budaya merupakan sesuatu yang berkaitan dengan kebudayaan yang telah berkembang, beradab, dan maju. Keempat, budaya adalah suatu kebiasaan yang melekat dan sukar merubahnya (Kebudayaan, 1991).

Menurut para ahli yaitu Selo Soemardjan, Linton, dan Greet Hifstede dalam (Antara \& Yogantari, 2018). Selo Soemardjan berpendapat bahwa budaya merupakan buah dari cipta, rasa, serta karya suatu kelompok masyarakat. Sementara menurut Linton, budaya merupakan seluruh pola perilaku serta sikap seseorang yang dilatarbelakangi oleh hasil pemikiran dan juga pengetahuan dari suatu masyarakat tertentu, kemudian menjadi kebiasaan yang diwariskan kepada generasi selanjutnya. Sedangkan menurut Geert Hifstede, budaya merupakan konsep kesepakatan bersama yang dilandasi dari hasil pemikiran seseorang yang mampu membedakan antara satu anggota dengan anggota lainya ataupun kelompok satu dengan yang lainya.

Sedangkan menurut Kotter dan Heskett dalam (Fathurrohman, 2016), budaya merupakan pola perilaku secara utuh dari suatu keyakinan, kesenian, serta seluruh prodak dari kreasi pikiran seseorang yang memberikan makna terhadap suatu keadaan masyarakat ataupun penduduk tertentu. Sementara menurut Asmaun sahlan dalam (Putra, 2017), kata budaya bermula dari kajian ilmu antropologi sosial yang memiliki makna terhadap suatu perilaku, kesenian, kepercayaa, dan seperangkat hasil dari pemikiran 
manusia yang merepresentasikan kondisi dari masyarakat atau penduduk tertentu dan dalam peraktiknya menjadi suatu konsesnsus bersama-sama.

Sehingga dapat disumpulkan bahwa budaya adalah keseluruhan dari perilaku serta kebiasaan dalam konteks masyarakat yang merupakan hasil dari pikiran serta pengetahuan manusia yang disepakati secara bersama-sama dan merupakan representasi dari gambaran dari suatu kondisi penduduk atau masyarakat tertentu yang kemudian diwariskan kapada generasi selanjutnya secara turun temurun.

Menurut Kluckhohn dalam (Antara \& Yogantari, 2018) suatu kebudayaan mengandung beberapa unsur didalamnya yaitu: Pertama, merupakan suatu sistem dari religi atau kepercayaan. Kedua, merupakan hasil dari sistem pengetahuan seseorang. Ketiga, bagian dari sistem teknologi yang dalam hal ini mencakup berbagai macam peralatan serta kelengkapan hidup manusia. Keempat, berkaitan dengan sistem sosial atau kekerabatan sutau masyarakat. Kelima, merupakan suatu sistem ekonomi yang dalam konteks ini berkaitan dengan mata pencaharian hidup (pekerjaan). Keenam, bahasa (alat komunikasi masyarakat). Ketujuh, berkenaan dengan suatu kesenian.

Sehingga dalam hal ini unsur-unsur dari suatu kebudayaan meliputi seluruh aspek kehidupan manusia dalam konteks kemasyarakatan yang tercipta dari pola perilaku tertentu serta berkenaan dengan unsur keyakinan dan juga kebiasaaan atau adat istiadat terntentu sebagai bentuk dari pemenuhan kebutuhan hidup seseorang.

Suatu kebudayaan dalam konteks kehidpuan masyarakat memiliki fungsi serta peranan tertentu seperti yang diutarakan oleh Bascom dalam (Manuaba, 1999) diantaranya: Pertama merupakan suatu cerminan dari hasil pemikiran manusia secara kolektif yang terwujud menjadi suatu makna dalam sistem proyeksi kehidupan manusia. Kedua, merupakan seperangkat alat yang dapat digunakan untuk mengatur norma-norma dalam suatu kehidupan masyarakat serta harus dipatuhi secara bersama-sama. Ketiga, dapat dijadikan suatu alat untuk membentuk karakter serta mendidiki anak keturunan. Keempat, merupakan suatu sarana dalam mengatur pranat-pranata atau Lembagalembaga kebudayaan yang ada dalam suatu kehidupan masyarakat.

Dalam aspek yang lain, terdapat ciri-ciri yang khas pada suatu kebudayaan diantaranya: Pertama, tidak terbatas oleh ruang dan waktu tertentu sehingga budaya tersebut dapat disampaikan oleh generasi satu kepada generasi selanjutnya, kelompok satu pada kelompok lainya juga dari orang ke orang. Kedua, budaya bukan merupakan faktor bawaan sejak lahir akan tetapi perlu dipelajari melalui pengetahuan tertentu yang kemudian dalam prosesnya berpengaruh terhadap karakter seseorang. Ketiga, terdapat symbol tertentu dalam suatu budaya. Keempat, budaya memiliki kecenderungan yang selektif, artinya budaya dalam konteks penerimaanya terbatas karena merupakan hasil dari seleksi seseorang dalam merepresentasikan pola perilaku kehidupanya. Kelima, budaya tidak pakem pada satu hal dan bersifat dinamis (berubah sepanjang waktu) bergantung pada seseorang dalam mempertahankanya atau justu merubahnya berdasarkan hasil dari suatu konsesnsus. Keenam, unsur-unsur dari budaya akan saling berkaitan didalamnya. Ketujuh, menunculkan sifat entnosentrik, dalam artian dapat 
menimbulkan persepsi bahwa budaya sendiri adalah yang "terbaik" (Antara \& Yogantari, 2018).

Pada konteks ke-Indoensiaan, budaya memiliki keterkaitan yang sangat erat dengan kondisi masyarakatnya. Karena pada dasarnya Indonesia merupakan suatu negara majemuk yang mana didalamnya memiliki banyak sekali hasil dari produk suatu kebudayaan yang didasari oleh kearifan budaya lokalnya yang beranekaragam serta memiliki ciri khasnya masing-masing. Maka dalam hal ini kehidupan masyarakat Indonesia pada setiap daerahnnya menghasilkan suatu budaya tertentu dan juga dalam konteks ini terakui sebagai suatu kebudayaan sebagaimana yang tercantum dalam UUD 1945 pasal 32 bahwa "kebudayaan bangsa adalah kebudayaan yang timbul sebagai usaha budinya rakyat Indonesia” (Brata, 2016). Sehingga pada faktanya menunjukan bahwa budaya nusantara merupakan suatu hasil dari usaha rakyat Indonesia yang terbentuk melalui adat istiadat kedaerahan serta kearifan lokalnya masing-masing.

Diantara berbagai macam produk kebudayaan bangsa Indonesia, busana kebaya merupakan salah satunya. Dimana istilah kebaya sendiri berasal dari bahasa Arab yaitu "kaba" yang berarti "pakaian". Kemudian dalam prosesnya dinisbatkan pada suatu pakaian atas yang dikenakan oleh seorang perempuan dengan bentuk lengan yang panjang. Yang mana menurut Lombard, budaya adalah suatu atasan (blous) yang merupakan ciri khas dari perempuan Indonesia dan sudah melekat pada masyarakat dari sejak abad ke-15, yang dalam kurun waktu tersebut masih merupakan suatu pakaian khas dari permpuan yang ada di Jawa (Dewi et al., 2015).

Pada kamus mode Indonesia dalam (Trismaya, 2019) kebaya adalah suatu pakaian tradisional perempuan yang ada di Indonesia berupa atasan atau bus dengan lengan yang panjang dan terdapat bukaan didepanya. Panjang dari ukuranya bervariasi mulai dari yang sepinggul (pendek) hingga yang mencapai betis (panjang) dan biasa dipakai dengan sarung kain secara bersamaan untuk bagian bawahanya (melilit tubuh dari pinggang ke mata kaki).

Dalam prosesnya busana kebaya terlegitimasi menjadi suatu identitas budaya nusantara serta memiliki makna secara filosofis dari nilai-nilai kehidupan dan merupakan cerminan dari kepribadian perempuan yang ada di Indonesia. Yang melambangkan karakteristik perilaku yaitu sopan santun, anggun, penuh dengan kelembutan (Yuastanti, 2016). Sehingga busana kebaya sendiri selain manjadi pakaian yang merupakan prodak dari budaya Indonesia, juga merupakan suatu representasi perempuan Indoensia dalam menyampaikan karakteristik dari perilakunya.

Busana kebaya sebagai salah satu identitas bangsa Indonesia mulai diakui menjadi suatu busana nasional sejak diselanggarakanya lokakarya pada tahun 1978 di Jakarta. Dimana dalam acara menghadirkan utusan dari seluruh provisi yang ada di Indonesia pada saat itu (28 provinsi), dengan menetapkan secara nasional busana kebaya sebagai salah satu identitas bangsa Indonesia yang memiliki karakteristik pakaian atasan dengan kain yang panjang dan diwiru sebagai busana bawahanya. Dimana pada saat yang bersamaan juga di tetapkan role model dari kebaya nasional Indonesia adalah seperti yang dikenakan oleh Raden Ayu Siti Hartinah yang lebih dikenal (akrab) dengan sebutan ibu 
Tien Soeharto dimana pada saat itu beliau merupakan istri dari presiden republik Indonesia yaitu Jendral Besar TNI (purn) H. M. Soeharto. Kemudian dengan adanya penetapan tersebut ibu Tien selalu mengenakan busana kebaya dalam berbagai acara kenegaraan (nasioanal/internasional) dengan tujuan untuk mengenalkan busana kebaya pada khalayak umum sebagai suatu identitas busana perempuan Indoensia yang diakui secara nasional. (Suciati et al., 2015).

Sehingga dalam hal ini busana kebaya dalam perkembanganya bukan lagi menjadi salah satu budaya tradisi kedaerahan tertentu, namun telah menjadi cerminan fashion serta gaya hidup dari perempuan Indonesia pada dewasa ini. Dimana pada perempuan masa kini mengenakan kebaya bukan lagi dilandasi terhadap prasangka etnis tertentu, akan tetapi dilatarbelakangi oleh ketertatikan pada jenis desain yang mengandung nilai-nilai estetika yang tinggi.

Di berbagai daerah Indonesia busana kebaya dapat di temui dengan berbagai macam karakteristik yang menjadi ciri khas kedaerahanya masing-masing, diantaranya: kebaya panjang (Sumatera Utara), bejee plah dada (Aceh), kebaya pendek (Sumatera Barat), kebaya labuh (Riau), kebaya landoong (Sumatera Selatan), kebaya panjang (Bengkulu), kebayau (Lampung), Kebaya (Jawa Barat), kebaya panjang (DKI Jakarta), kebaya (Jawa Tengah dan Jawa Timur), kebaya (Bali), tangkong kebaya (NTB), kebaya (Kalimantan Barat), kubaya (Kalimantan Selatan), baju kustim dan takwo (Kalimantan Timur), kebaya wuyang (Minahasa), kebaya (Maluku). (Putri \& Hidayat, 2003)

Fakta tersebut membuktikan bahwa kebaya sebagai salah satu identitas perempuan Indonesia telah menyebar ke berbagai daerah nusantara dengan memiliki ciri khasnya masing-masing sebagai bentuk dari adanya akulturasi dengan proses kebudayaan. Akan tetapi perlu diperhatiakan kembali bahwa mayoritas dari perempuan Indonesia adalah seorang muslimah (penganut agama Islam) dengan fakta bahwa jumlah umat Islam yang ada di Indonesia sekitar $85 \%$ dan $15 \%$ nya merupakan penganut agama lain seperti Katolik, Konghucu, Protestan, Budha, dan Hindu (Hisyam, 2006). Sehingga pakaian yang dikenakan oleh seorang muslimah harus selaras dengan aturan yang ada dalam ajaran agama Islam. Karena pada hakikatnya hal tersebut muncul sebagai suatu perhatian terhadap seorang permpuan yang dalam Islam sendiri di jungjung tinggi martabat, kemuliaan, serta kehormatanya. Maka dalam konteks ini perlu dikaji kembali bagaimana sudut pandang dari Agama Islam terkait dengan busana kebaya yang menjadi suatu identitas dari perempuan/muslimah yang ada di Indonesia.

\section{Kebaya dalam Sudut Pandang Islam.}

Dalam ranah kehidupan manusia, Islam sebagai suatu agama hadir dalam membahas persoalan-persoalan dan juga berbagai macam problema yang menyangkut dengan kehidupan manusia tersebut. Khususnya dalam kaitan ini membahas mengenai perempuan atau seorang muslimah, yang notabene memiliki posisi yang sentral dalam kemuliaan serta kehormatanya. Fakta sejarah menunujukan bahwa agama Islam memperlakukan seorang perempuan lebih baik ketimbang ajaran agama lainya, seperti yang terjadi pada zaman jahiliyah (sebelum Islam hadir) posisi dari perempuan sangat 
terbelakang dan cenderung dianggap hanya sebelah mata (direndahkan) lebih parahnya lagi terkadang diperlakukan dengan tidak manusiawi. Namun setelah ajaran Islam hadir, semua permasalahan tersebut diatasi dengan memposisikan perempuan lebih terhormat dan mulia sebagai mahluk ciptaan Allah dimana perempuan juga memiliki hak yang sama dalam menjalankan kehidupanya di alam dunia ini.

Kehormatan dan kemuliaan tersebut juga dapat terlihat dari dinisbatkanya perempuan dalam salah satu surah yaitu "An-Nisa" yang dalam konteks ini mengandung makna bahwa agama Islam juga konsern terhadap asepk-aspek yang berkaitan dengan seorang perempuan (Abidin, 2015), juga terdapat surah lain "Maryam" yang merupakan tokoh perempuan yang ta'at serta surah "Al-Mujadalah" yang berarti "wanita yang mengajukan gugatan" dan surah "Almumtahanah" yang berarti "Wanita yang diuji".

Berkaitan dengan pembahasan ini, Islam juga telah mengatur mengenai cara berpakaian baik laki-laki ataupun perempuan pada khususnya. Yang mana memiliki tujuan agar umat manusia dapat menjalankan kehidupanya denga naman, tentram dan damai. Juga dalam aspek lain mencegah terjadinya suatu tindak kekerasan yang dalam hal ini perempuan sering kali menjadi sasaran ataupun dirugikan dan tata cara berpakaian menjadi salah satu latar belakangnya. Anjuran untuk mengenakan pakaian baik bagi lakilaki ataupun perempuan termaktub dalam Al-Qur'an, sebagaimana firman Allah "Hai anak Adam, sesungguhnya kami telah menurunkan pakaian untuk menutupi auratmu dan pakaian indah untuk perhiasan. Dan pakaian takwa itulah yang paling baik. Yang demikian itu adalah Sebagian dari tanda-tanda kekuasaan Allah, mudah-mudahan mereka selalu ingat" (Q.S. Al-A'Raaf 7:26).

Dalam ayat lainya, Allah SWT berfirman "Hai Nabi, katakanlah kepada istriistrimu, anak-anak perempuanmu dan isteri-isteri orang mukmin: hendaklah hendaklah mereka mengulurkan jilbabnya keseluruh tubuh mereka. Yang demikian itu supaya mereka lebih mudah untuk dikenal, karena itu mereka tidak diganggu. Dan Allah adalah Maha pengampun lagi Maha penyayang". (Q.S Al-Ahzaab 33:59).

Berdasarkan ayat-ayat tersebut, Allah SWT telah memerintahkan pada hambahambaNya mengenakan pakaian sebagai alat untuk menutupi aurat. Terkhusus dalam konteks perempuan yang dalam fitrahnya dianugrahi rasa malu yang tinggi, sehingga dengan menuturp aurat maka perempuan telah menunikan fitrahnya. Namun jika perempuan keluar dati fitrahnya tersebut (tidak menutup aurat) maka aspek negatif akan muncul seperti menampakan kemolekan bentuk tubuhnya pada khalayak umum (bukan muhrimnya) yang pada saat bersamaan akan merangsang gairah dari lawan jenisnya serta tidak jarang berujung pada terjadinya suatu tindakan kekerasan seksual yang dalam hal ini justru dapat merugikan perempuan itu sendiri (Yuliani, 2010).

Pada ayat yang lain, Allah SWT berfirman "Katakanlah kepada wanita yang beriman: Hendaknya mereka menahan pandangan mereka, dan memelihara kemaluan mereka, dan janganlah mereka menampakkan perhiasan mereka kecuali yang (biasa) nampak dari mereka. Dan hendaklah mereka menutupkan kain kudung ke dada mereka, dan janganlah menampakan perhiasan mereka, kecuali kepada suami mereka, atau ayah mereka atau ayah suami mereka, atau putera-putera mereka atau putera-putera suami 
mereka, atau saudara-saudara laki-laki mereka, atau putera-putera saudara laki-laki mereka, atau putera-putera saudara perempuan mereka, atau wanita-wanita Islam, atau budak-budak yang mereka miliki atau pelayan-pelayan laki-laki yang tidak mempunyai keinginan (terhadap wanita), atau anak-anak yang belum mengerti tentang aurat wanita. Dan janganlah mereka memukulkan kaki mereka agar diketahui perhiasan yang mereka sembunyikan. Dan bertaubatlah kamu sekalian kepada Allah, hai orang-orang yang beriman supaya kamu beruntung" (Q.S An-Nuur 24:31).

Tengku Muhammad Hasbi As-Shiddieqy memaknai ayat tersebut yang terdapat dalam tafsirnya Al-Quranul Majid An-Nur menjelaskan bahwa aurat (bagian tubuh) yang dilarang ditampakan pada yang bukan mahramnya yaitu untuk laki-laki adalah wilayah tubuh antara perut dengan lututnya, sedangkan bagi perempuan yaitu keseluruhan tubuhnya kecuali bagian telapak dangan dan wajahnya. Yang mana telapak tangan dan wajah tersebut merupakan hal yang wajar dan boleh dilihat oleh laki-laki yang bukan mahramnya. Serta adanya larangan tersebut ketika lawan jenis melihat aurat tersebut ketika dalam keadaan tebuka (Nurrohim \& Jannah, 2008).

Akan tetapi dalam hadits Nabi Saw ada istilah "berpakaian namun dianggap telanjang" yang kemudian dilarang dan dilaknat oleh Rasulullah Saw sendiri. Karena pernyataan tersebut mengandung makna bahwa pakaian ketat yang digunakan justru akan menampakan aurat yang dapat memunculkan syahwat terhadap lawan jenisnya dan jelas bahwa hal tersebut dilarang dalam ajaran agama Islam. Sebagaimana termaktub dalam hadits dari Abdullah bin 'Amr bin al-'Ash Radhiyallahu anhu, bahwa Rasulullah Saw bersabda; "Pada akhir umatku akan ada kaum pria yang menunggang di atas pelanapelana kuda bagaikan rumah-rumah (1). Mereka turun di pintu-pintu masjid, Wanita-wanita mereka berpakaian tetapi telanjang, kepala mereka bagaikan punuk unta yang kurus (2). Laknatlah mereka karena sesungguhnya mereka adalah Wanita-wanita terlaknat. Seandainya setelah kalian ada salah satu umat, niscahya Wanita-wanita kalian akan menjadi pembantu bagi Wanita-wanita mereka sebagaimana Wanita-wanita sebelum kalian menjadi pembantu bagi Wanita-wanita kalian.” (HR. Imam Ahmad)

Pada hadits yang lain, dari abu Hurairah radhiyallahu 'anhu, beliau berkata bahwa Rasulullah Saw, bersabda: "Ada dua golongan dari penduduk neraka yang belum pernah aku lihat 1). Suatu kaum yang memiliki cambuk seperti ekor sapi untuk memukul manusia dan 2). Para Wanita yang berpakaian tapi telanjang, berlenggak-lenggok, kepala mereka seperti punuk unta yang miring. Wanita seperti itu tidak akan masuk surga dan tidak akan mencium baunya, walaupun baunya tercium selama perjalanan sekian dan sekian". (HR. Muslim no. 2128)

Maka dalam konteks ini, ajaran agama islam melalui sumber hukum tertingginya yaitu Al-Qur'an dan Hadits telah mengatur bagaimana seorang muslimah dalam hal berpakaian yang tentunya dengan tujuan untuk memuliakan serta menjaga kehormatan dari perempuan tersebut. Muhammad Quraish Sihab dalam menafsirkan surah Al-Ahzaab ayat 59 dan surah An-Nuur ayat 31 berpendapat bahwa anjuran cara berpenampilan seorang muslimah adalah sebagai berikut: Pertama, pakaian yang dikenakan harus longgar (tidak sempit). Kedua, bagian dada harus tertutup oleh kain yang dijulurkan. 
Ketiga, tidak menampakan perhiasan yang ada pada tubuhnya. Keempat, dianjurkan untuk tidak menggunakan wewangian secara berlebih yang pada sisi lain dapat merangsang lawan jenisnya. Meskipun beliau menetapkan cara berpakian seorang muslimah, namun beliau menekankan bahwa seorang muslmah tidak diwajibkan untuk menutup auratnya kendatipun seorng muslimah memilih untuk menutup keseluruhan dari tubuhnya maka hal tersebut lebih baik (Nurrohim \& Jannah, 2008).

Sementara itu, menurut Nasaruddin Al-Albani dalam (Wijayanti, 2017), berpendapat bahwa syarat-syarat bagi seorang muslimah dalam berbusana diantaranya: Pertama, pakaian yang dikenakan harus menutupi keseluruhan bagian dari badan kevuali muka dan telapak tangan. Kedua, busana yang dikenakan tidak terlalu glamor dan bukan menampakan perhiasan kecantikan. Ketiga, bukan busana yang tipis (rangkap). Keempat, harus longgar dan tidak ketat (sempit) agar tidak menampakan bentuk tubuh. Kelima, dalam menggunakan wewangian tidak boleh berlebihan. Keenam, dapat dibedakan dengan busana yang dikenakan oleh laki-laki (tidak serupa). Ketujuh, tidak menyamai pakaian yang dikenakan oleh perempuan yang kafir. Kedelapan, bukan pakaian yang aneh dan dapat menarik perhatian.

Dari beberapa keharusan serta anjuran bagi seorang muslimah dalam berbusana, seharusnya diaplikasikan juga dalam kaitanya terhadap busana kebaya yang dikenakan oleh muslimah yang ada di Indonesia. Walaupun di sisi lain perempuan dianugrahi fitrah untuk merias diri, berpakaian indah, juga berdandan. Namun ajaran agama Islam sebenarnya telah mengatur itu semua yang pada penerapannya tergantung dari situasi serta kondisi terentu dan sesuai dengan porsinya (Nurrohim \& Jannah, 2008). Hal tersebut dapat dilihat dari kebolehan seorang muslimah untuk mempercantik diri dihadapan muhrimnya (bukan di tempat umum) dengan tujuan agar tidak terjadi hal-hal yang justru dapat merugikan serta merendahkan derajat perempuan itu sendiri.

Seiring dengan berkembangnya zaman, desain dari kebaya sendiri mengalami perkembangan yang cukup pesat dari segi jenis, serta modelnya. Sehingga pada praktiknya busana kebaya mengikuti tren mode yang sedang berkembang. Dalam dunia mode sendiri, ketika seseorang tertinggal dengan mode terbaru maka kerapkali muncul stigma orang tersebut tidak fashionable dan ketinggalan zaman. Pada aspek lain, suatu pakaian juga mengandung makna serta fungsi didalamnya yang dapat digunakan sebagai pembeda antara profesi satau dengan profesi yang lainya seperti pakaian untuk kantoran, liburan, acara-acara resmi dan juga melambangkan dari suatu simbol stata sosialnya (Rahmawati, 2017). Kemudian yang menjadi permasalahan adalah ketika busana kebaya tersebut mengikuti mode perkembangan zaman yang justru pada saat bersamaan melanggar aturan berbusana yang ada dalam ajaran Islam, karena memang pada faktanya justru tren mode pakaian lebih condong mengikuti perkembangan yang ada di barat dan negara-negara lain yang mayoritasnya bukan agama Islam. sehingga kurang memperhatikan aspek aurat terhusus yang ada pada perempuan, karena memang ajaran agama islam sendiri mengatur hal tersebut agar mencegah timbulnya kemadharatan dan lebih mengutamakan sisi kemaslahatanya. 
Kebanyakan pada desaian kebaya yang berkembang saat ini justru menampakan lekuk tubuh dari seorang perempuan yang kemudian pada saaat bersamaan memunculkan stigma yang negatif pada kebaya itu sendiri dalam kacamata agama Islam. Dimana dalam hal ini seperti yang telah dibahas sebelumnya dalam Al-Quran surah An-Nur ayat 31, bahwa aurat dari seorang perempuan dilarang untuk diperlihatkan kepada yang bukan mahramnya juga yang terdapat dalam hadist Rasulullah Saw, bahwa beliau melaknat seseorang yang "berpakaian namun dianggap telanjang” atau dalam hal ini mengenakan pakaian yang ketat yang dapat memancing syahwat lawan jenisnya. Maka ketika busana kebaya itu justru memperlihatkan lekuk tubuh dan juga menampakan sisi sensualitas dari perempuan maka hal tersebut dilarang dalam agama Islam.

Padahal dalam sejarahnya, busana kebaya dahulu berbeda dengan kebanyakan kebaya yang ada pada zaman sekarang. Dahulu kebaya mempunyai bentuk yang longgar dan tidak menampakan bentuk lekuk tubuh dan sisi sensualitas dari perempuan dan juga memiliki desain yang sederhana. Jika diruntut dari segi pengertianya kata "kebaya" sendiri berasal dari bahasa Arab yaitu "kaba" yang miliki arti "pakaian". Yang mana dahulu pertama muncul dibawa oleh bangsa Arab ke wilayah nusantara pada abad ke-15 dan ke-16 yang kemudian terjadi proses akulturasi dengan budaya lokal yang ada di nusantara (Putri \& Hidayat, 2003). Berdasarkan fakta tersebut bahwa memang kebaya dahulu sesuai dengan aturan yang ada dalam ajaran agama Islam dalam bebusana. Yang mana bangsa Arab pada saat itu datang ke bumi nusantara selain melakukan ekspansi dagang juga membawa misi mulia yaitu menyebarkan ajaran Agama Islam ke wilayah selain jazirah Arab.

Maka dalam hal ini, agama Islam memandang busana kebaya dilihat dari proses penggunaanya serta kategori-kategori yang diharuskan sesuai dengan aturan yang ada. Apabila busana kebaya tersebut sesuai dengan anjuran yang ada dalam ajaran agama Islam bagi seorang muslimah dalam berbusana maka hal tersebut diperbolehkan untuk dikenakan. Namun apabila kebaya tersebut bertentangan dengan aturan yang ada dalam agama Islam, maka jelas hal tersebut dilarang dan tidak di perkenankan digunakan oleh seorang mulimah yang ada di Indonesia. Sehingga busana kebaya yang diperbolehkan dalam hal ini adalah yang longgar, tidak memperlihatkan bentuk lekuk tubuh, serta sisi dari sensualitas perempuan dan dapat menutupi auratnya.

\section{Kesimpulan}

Busana kebaya sebagai salah satu identitas perempuan Indonesia dan merupakan hasil dari prodak kebudayaan pada prosesnya mengalami perkembangan yang luar biasa. Seiring dengan berkembangnya fashion dan mode pakaian pada era globalisasi seperti sekarang ini. Disamping merupakan suatu prodak dari budaya nusantara dan terlegitimasi pada perempuan yang ada di Indonesia, perlu di perhatikan kembali bahwa mayoritas dari perempuan yang ada di Indonesia merupakan seorang muslimah (penganut agama Islam) yang notabene dalam hal ini memiliki tata cara serta aturan tersendiri dalam menetapkan pakaian yang telah diatur dalam ajaran agama Islam. 
Dengan seperangkat hukum yang ada dalam agama Islam seperti Al-Qur'an, Hadits, serta sumber hukum lainya, anjuran bagi seorang muslimah dalam berpakaian telah diatur sedemikian rupa yang memiliki tujuan untuk menjaga kehormatan, kemuliaan, serta martabat dari perempuan itu sendiri agar terhindar dari hal-hal yang justru akan merugikan dan mengandung kemadharatan didalamnya.

Sehingga dalam persfektif agama Islam busana kebaya yang dikenakan oleh seorang muslimah terkhusus yang ada di Indoensia harus sesuai dengan aturan yang ada dalam ajaran Islam yaitu dapat menutupi aurat perempuan, tidak memperlihatkan bentuk lekuk tubuh, serta tidak menampkan sisi sensualitas dari perempuan yang dalam hal ini dapat memancing gairah syahwat lawan jenisnya juga tidak menutup kemungkinan terjadinya suatu tindak kerasan seksual pada perempuan dan secara bersamaan justru malah merendahkan derajat dan kemuliaan perempuan tersebut yang notabene sangat dijungjung tinggi harkat derajat martabat, kemuliaan, serta kehormatannya dalam agama Islam itu sendiri. Maka apabila busana kebaya yang digunakan tersebut sesuai dengan aturan yang ada dalam agama Islam maka boleh-boleh saja dikenakan oleh seorang muslimah, akan tetapi jika hal tersebut malah bertentangan maka tidak di pebolehkan untuk dikenakan. 


\section{Bibliografi}

Abidin, Z. (2015). Kesetaraan Gender Dan Emansipasi Perempuan Dalam Pendidikan Islam. Tarbawiyah: Jurnal Ilmiah Pendidikan, 12(01), 1-17.

Brata, I. B. (2016). Kearifan Budaya Lokal Perekat Identitas Bangsa. Jurnal Bakti Saraswati, 05(01), 9-16.

Dewi, P. S. A., Kebayantini, N. L. N., \& Ranteallo, I. C. (2015). Kebaya Sebagai Media Presentasi Diri Perempuan Bali Di Kelurahan Ubud, Gianyar. Jurnal Ilmiah Sosiologi (Sorot), 1(3), 1-11.

Fathurrohman, M. (2016). Meningkatkan Mutu Pendidikan Bangsa. Jurnal Ta'allum, 04(01), 19-42.

Hisyam, M. (2006). Agama Dan Konflik Sosial. Jurnal Masyarakat Dan Budaya, 8(2), $141-152$.

Inawati, A. (2014). Peran Perempuan Dalam Mempertahankan Kebudayaan Jawa Dan Kearifan Lokal. Musãwa Jurnal Studi Gender Dan Islam, 13(2), 195-206.

Departemen Pendididakn Dan Kebudyaaan (1991). Kamus Besar Bahasa Indonesia. Pt Balai Pustaka.

Manuaba, P. (1999). Budaya Daerah Dan Jati Diri Bangsa : Pemberdayaan Cerita Rakyat Dalam Memasuki Otonomi Daerah Dan Globalisasi. Masyarakat, Kebudayaan Dan Politik, 12(4), 57-66.

Mustofa, N. S., Maemunah, S., \& Kustanto, L. (2019). Analisis Makna Tanda Pada Film Kartini:Resistensi Perempuan Terhadap Budaya Patriarki. Sense, 02(01), 71-81.

Nurul, Mas'ud Waqiah. (2018). Peran Perempuan Dalam Melestarikan Berbagai Tradisi Lokal Rodiyah. Tsaqofah \& Tarikh, 3(1), 65-72.

Putra, K. S. (2017). Implmentasi Pendidikan Agama Islam Melalui Budaya Religius (Religious Culture) Di Sekolah. Jurnal Kependidikan, 3(2), 14-32.

Putri, N. A., \& Hidayat, A. A. (2003). Budaya Indis Pada Kebaya Abad Ke-20. Historia Madania, 05(01), 49-64.

Rahmawati, I. (2017). Semiotik Teks Roland Barthes Dalam Kehidupan Kontemporer Umat Beragama Mengenai Fenomena Padu Padan Kebaya. Tamaddun: Jurnal Kebudayaan Dan Sastra Islam, 17(02), 1-14.

Rositadewi, F. D. (2020). Kebaya: Belenggu Konservatif Perempuan Muslim. Jurnal Hawa : Studi Pengarus Utamaan Gender Dan Anak, 02(02), 204-218.

Suciati, Sachari, A., \& Kahdar, K. (2015). Nilai Femininitas Indonesia Dalam Desain Busana Kebaya Ibu Negara. Ritme, 1(1), 52-59.

Trismaya, N. (2019). Kebaya Dan Perempuan: Sebuah Narasi Tentang Identitas. Jsrw (Jurnal Senirupa Warna), 6(2), 151-159.

Wijayanti, R. (2017). Jilbab Sebagai Etika Busana Muslimah Dalam Perspektif AlQur'an. Cakrawala: Jurnal Studi Islam, 12(2), 151-170.

Yuliani, S. (2010). Tubuh Perempuan: Medan Kontestasi Kekuasaan Patriarkis Di Indonesia. Dilema: Jurnal Sosiologi, 25(02), 98-106. 